\title{
Inhibition of the MAP2K7-JNK pathway with 5Z-7-oxozeaenol induces apoptosis in T-cell acute lymphoblastic leukemia
}

\author{
Taylor J. Chen ${ }^{1}$, Wa Du ${ }^{1}$, Jacob J. Junco ${ }^{2}$, Cory Seth Bridges ${ }^{1}$, Ye Shen ${ }^{1}$, Monica \\ Puppi $^{1}$, Karen R. Rabin ${ }^{2}$ and H. Daniel Lacorazza ${ }^{1}$ \\ ${ }^{1}$ Department of Pathology \& Immunology, Baylor College of Medicine, Houston, TX, USA \\ ${ }^{2}$ Texas Children's Cancer Center, Department of Pediatrics, Baylor College of Medicine, Houston, TX, USA \\ Correspondence to: H. Daniel Lacorazza, email: hdl@bcm.edu
}

Keywords: T-ALL; MAP2K7; 5z-7-oxozeaenol

Received: June 30, $2021 \quad$ Accepted: July 28, $2021 \quad$ Published: August 31, 2021

Copyright: () 2021 Chen et al. This is an open access article distributed under the terms of the Creative Commons Attribution License (CC BY 3.0), which permits unrestricted use, distribution, and reproduction in any medium, provided the original author and source are credited.

\section{ABSTRACT}

T-cell acute lymphoblastic leukemia (T-ALL) is an aggressive pediatric leukemia with a worse prognosis than most frequent B-cell ALL due to a high incidence of treatment failures and relapse. Our previous work showed that loss of the pioneer factor KLF4 in a NOTCH1-induced T-ALL mouse model accelerated the development of leukemia through expansion of leukemia-initiating cells and activation of the MAP2K7 pathway. Similarly, epigenetic silencing of the KLF4 gene in children with T-ALL was associated with MAP2K7 activation. Here, we showed the small molecule 5Z-7-oxozeaenol (5Z70) induces dose-dependent cytotoxicity in a panel of T-ALL cell lines mainly through inhibition of the MAP2K7-JNK pathway, which further validates MAP2K7 as a therapeutic target. Mechanistically, 5Z70-mediated apoptosis was caused by the downregulation of regulators of the G2/M checkpoint and the inhibition of survival pathways. The anti-leukemic capacity of 5270 was evaluated using leukemic cells from two mouse models of T-ALL and patient-derived xenograft cells generated using lymphoblasts from pediatric T-ALL patients. Finally, a combination of $\mathbf{5 Z 7 0}$ with dexamethasone, a drug used in frontline therapy, showed synergistic induction of cytotoxicity. In sum, we report here that MAP2K7 inhibition thwarts survival mechanisms in T-ALL cells and warrants future pre-clinical studies for highrisk and relapsed patients.

\section{INTRODUCTION}

Acute lymphoblastic leukemia (ALL) is the most common pediatric cancer, with more than 3,000 new cases diagnosed every year in the U.S. $[1,2]$. While advances in pediatric ALL therapies through systemic and intrathecal multi-drug treatment have vastly improved 5-year eventfree survival over $85 \%$ [3], relapsed ALL patients exhibit poor prognosis and remain the leading cause of pediatric cancer-related mortality [4-7]. ALL is broadly classified based on immunophenotype into B-cell or T-cell ALL, the latter being less frequent albeit with worse prognosis and higher rate of relapse. Relapses after induction therapy or following remission are caused by the outgrowth of drugresistant leukemic cells with leukemia initiating capacity. In order to provide therapeutic options for patients with refractory disease, it is essential to identify novel targets for the development of alternative therapies.

The mitogen-activated kinase kinase MAP2K 7 is an emerging target for anticancer drug therapy [8]. Our group described that the pioneer factor KLF4 inhibits homeostatic and antigen-driven proliferation of $\mathrm{T}$ cells and that genetic inactivation of KLF4 associates with more aggressive leukemia in NOTCH1-induced T-ALL mouse models and children with T-ALL by aberrantly activating the MAP2K7 signaling pathway [9-12]. This pathway is a three-tiered mitogen-activated protein kinase signaling composed by MAP3K, MAP2K (MAP2K7), and the c-jun N-terminal kinase (JNK) [13]. In response to stress signals, MAP3K activates MAP2K7 through phosphorylation at serine and threonine residues, which in turn activates JNK and downstream effectors like 
c-JUN and ATF2 [13, 14]. A loss-of-function study shows MAP2K7 mediates stress-induced JNK activation in mast cells and inhibits growth factor and antigen-driven proliferation of immune cells [15].

Pharmacological inhibition of JNK, the sole downstream substrate of MAP2K7, with the selective JNK inhibitor JNK-IN-8 and other drugs tested in clinical trials showed anti-leukemic properties in T-ALL, validating the MAP2K7-JNK pathway as a therapeutic target. However, JNK inhibition presents important caveats for clinical translation regarding low potency and off-target effects [9]. To overcome these limitations, we propose the direct inhibition of the MAP2K7 kinase as a novel therapeutic approach for T-ALL. Generation of small molecules able to selectively inhibit MAP2K7 has proven difficult in light of the prevalence of structural homology within the MAP2K family of proteins, especially in the ATP binding pocket [8]. Selective inhibition of MAP2K7 would reduce pleiotropic effects because MAP2K4 activates both p38 and JNK, whereas MAP2K7 only activates JNK, but a challenge is the functional and structural similarities between MAP2K4 and MAP2K7, the only known kinases able to activate JNK [16]. Analysis of the ATP binding pocket across the MAP2K family of proteins revealed a cysteine-218 located in the hinge region of MAP2K 7 that is not present in other MAP2K proteins, offering a window of opportunity for irreversible and selective inhibition $[8,17]$. In fact, the compound 5Z-7-oxozeaenol (5Z7O) possesses the unique ability to bind to the cysteine-218 in MAP2K7, although it can also inhibit other kinases such as TAK1 [18]. Overall, these data support MAP2K7 as a new therapeutic target in T-ALL and that pharmacological inhibition with small molecules may have therapeutic potential.

We report here the anti-leukemic properties of $5 \mathrm{Z7O}$ in T-ALL and show dose-dependent cytotoxicity in a panel of T-ALL cell lines through inhibition of MAP2K7. Mechanistically, 5Z7O induced DNA damage, inhibited cell proliferation and accumulated cells in G0 phase of the cell cycle, deregulated the G2/M checkpoint, and induced apoptosis. Further, $5 \mathrm{Z7O}$ selectively targets leukemic T cells in two T-ALL mouse models and patient-derived xenograft cells and shows synergism when combined with dexamethasone. These findings underscore the therapeutic potential of MAP2K7 inhibition for the treatment of T-ALL.

\section{RESULTS}

\section{T-ALL cell line response to MAP2K7 inhibition with 5Z-7-oxozeaenol}

The chemical compound 5Z-7-oxozeaenol (5Z7O, Figure 1A) has been described to bind a free cysteine residue located in the hinge region of the ATP binding pocket in MAP2K7 through covalent reaction
(Supplementary Figure 1) [18]. Based on our previous findings that patients with T-ALL exhibit aberrant activation of MAP2K7 [9], we decided to investigate the anti-leukemic properties of MAP2K7 inhibition with $5 Z 70$ in a panel of T-ALL cell lines using an EBVtransformed lymphoblastoid cell line (LCL) as a nonleukemic control. We found that $5 \mathrm{Z7O}$ treatment for 48 hours reduced cell viability in a dose-dependent manner with IC50 values ranging from $200 \mathrm{nM}$ for Molt3 to 1.1 $\mu \mathrm{M}$ for ALL-SIL, while LCL cells displayed an IC50 of $1.5 \mu \mathrm{M}$ (Figure 1B). Therefore, most T-ALL cell lines possessed significantly higher sensitivity compared to LCL cells (Figure 1C). These data suggest that $5 \mathrm{Z7O}$ inhibits leukemic cell viability either by inhibiting cell proliferation or inducing apoptosis and that some T-ALL cell lines (e.g., Molt3, KOPT-K1, and Jurkat) were more sensitive to $5 \mathrm{Z7O}$. Furthermore, we directly compared the anti-leukemic cytotoxicity of $5 \mathrm{Z7O}$ with the previously described JNK inhibitor (JNK-IN-8) [19]. Molt3, Jurkat, and KOPT-K1 cell lines were more sensitive to $5 \mathrm{Z7O}$ compared to JNK-IN-8, with an IC50 7-fold lower (Figure 1D). This finding suggests that MAP2K7 inhibition with $5 Z 7 O$ may be more effective than JNK inhibition in T-ALL.

\section{Z7O inhibits cell proliferation and induces apoptosis in T-ALL cells}

To investigate the cause of $5 \mathrm{Z7O}$ induced cytotoxicity in T-ALL cell lines, we conducted cell cycle analysis by flow cytometric detection of $\mathrm{Ki} 67$ and 7AAD in nuclei (Figure 2A). Jurkat cells showed a dose dependent accumulation in the sub-G1 phase of the cell cycle following $5 \mathrm{Z} 7 \mathrm{O}$ treatment for 48 hours, whereas P12-Ichikawa cells exhibited additional accumulation in the G0-phase of the cell cycle (Figure 2B). Further analysis revealed a correlation of sub-G1 content and IC50, Jurkat cells underwent rapid accumulation in sub-G1, whereas other cell lines displayed an accumulation at the G0 phase of the cell cycle (Figure 2C).

We next assessed the ensuing expression of annexin $\mathrm{V}$ by flow cytometry as a readout of cell death upon $5 \mathrm{Z7O}$ treatment (48 hours at IC50). Consistent with previous cell cycle analysis, most sensitive cell lines (Molt3, Jurkat, and KOPT-K1) showed a significant increase of annexin $\mathrm{V}$ positive cells while the rest of the T-ALL cell lines showed a moderate increase (Figure 2D and 2E). Next, we studied the time- and dose-dependency of $5 \mathrm{Z7O}$ using luminescent detection of Caspase-3 and Caspase-7 cleavage. We focused upon Jurkat (IC50: $0.45 \mu \mathrm{M}$ ) and P12-Ichikawa (IC50: $0.72 \mu \mathrm{M}$ ) cell lines to represent different responses and treated both cell lines with $1 \mu \mathrm{M} 5 \mathrm{Z7O}$, corresponding to IC50, and $3 \mu \mathrm{M} 5 \mathrm{Z7O}$ (4- and 6-fold higher than the IC50) at different times. Jurkat cells showed a peak of Caspases-3/7cleavage that shifted from 12 hours with $1 \mu \mathrm{M}$ to 6 hours with $3 \mu \mathrm{M} 5 \mathrm{Z7O}$ (Figure $2 \mathrm{~F}$ ). This assay 
also showed that $\mathrm{P} 12$-Ichikawa cells require higher $5 \mathrm{Z7O}$ concentration and prolonged time to display increased cleavage of Caspases-3/7 (Figure 2F). Collectively, these data suggest that $5 \mathrm{Z7O}$ inhibits cell proliferation and induces apoptosis in T-ALL cell lines.

\section{Inhibition of the MAP2K7-JNK pathway in T-ALL cells}

To confirm that $5 \mathrm{Z} 7 \mathrm{O}$ cytotoxicity is mediated through MAP2K7 inhibition, we assessed the MAP2K7
A<smiles>COc1cc(O)cc(/C=C/C[C@@H](O)[C@@H](O)C(=O)/C=C\CC(C)OC(=O)c2c(O)cc(OC)cc2O)c1</smiles>
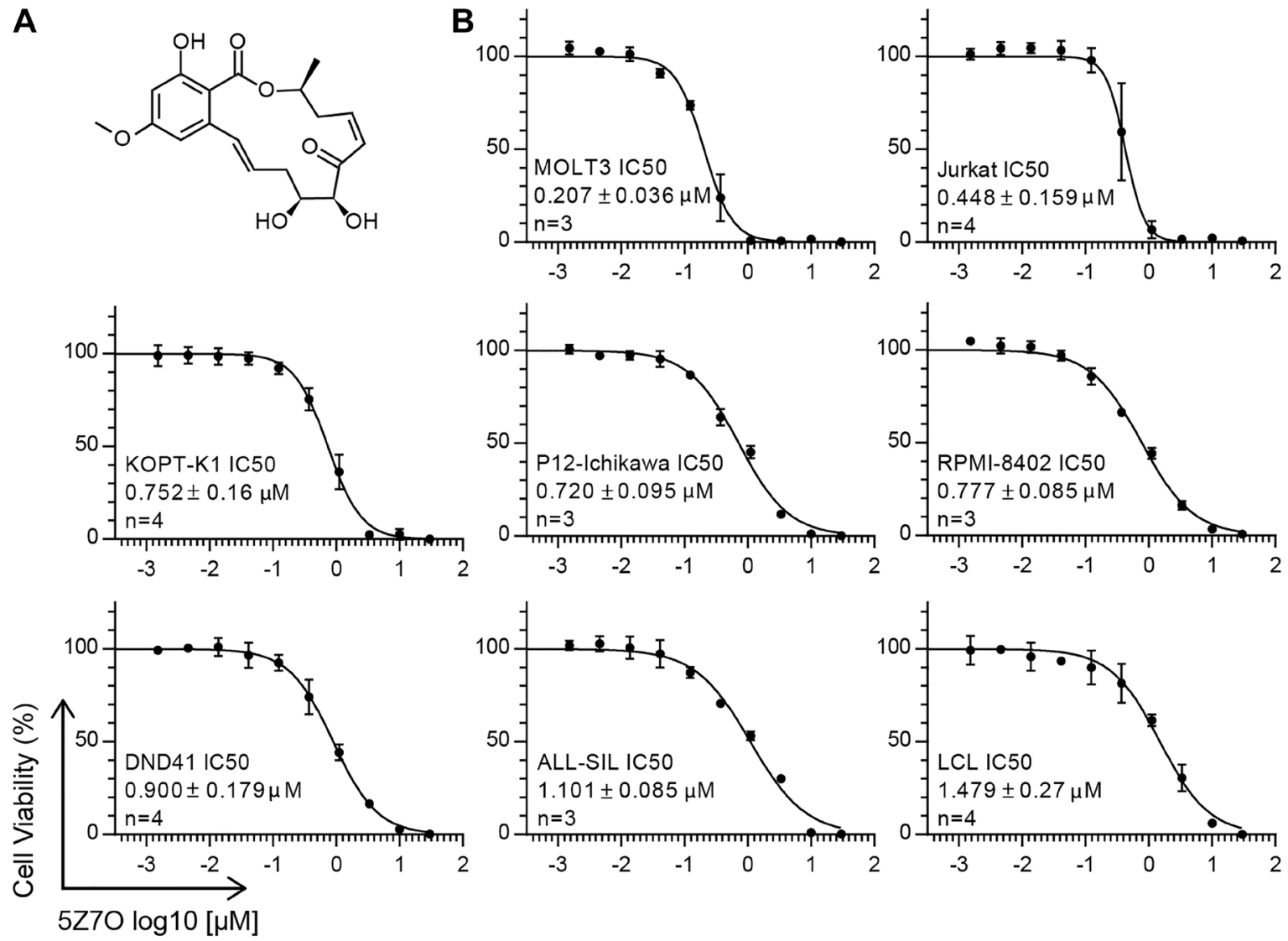
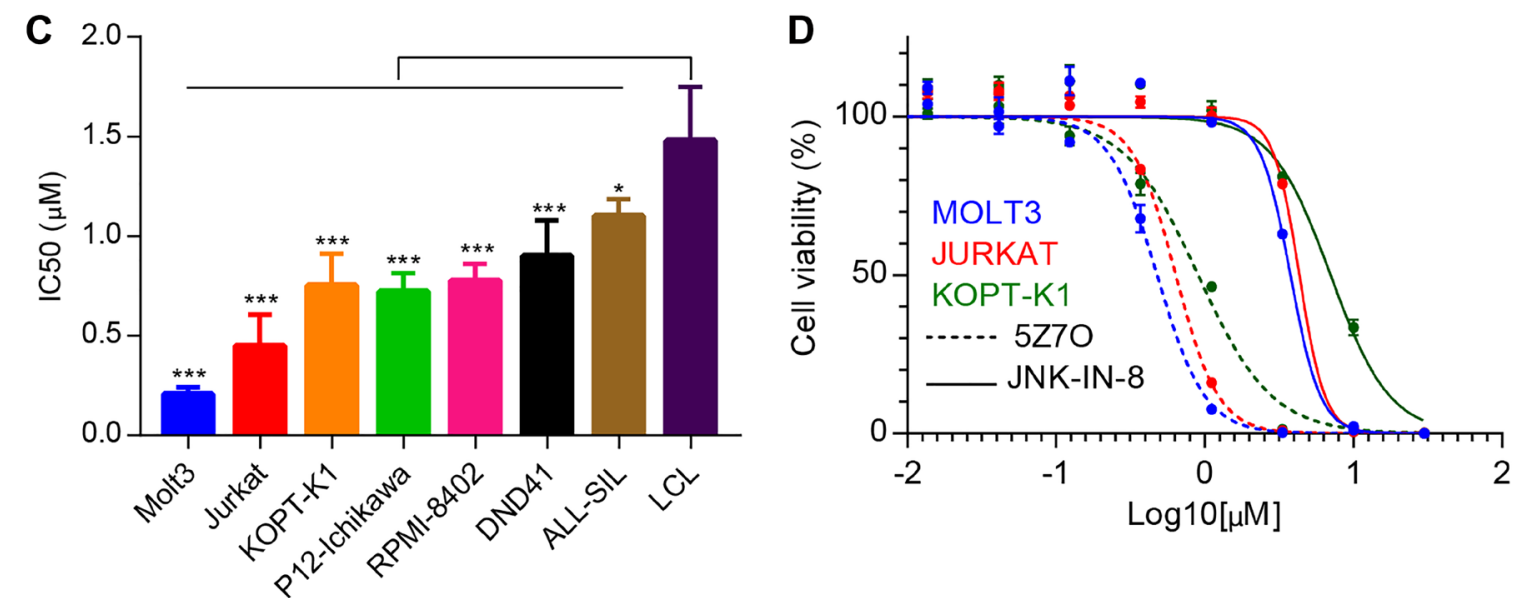

Figure 1: 5Z-7-oxozeaenol (5Z7O) inhibits cell viability in T-ALL cell lines. (A) Chemical structure for 5Z7O. (B) Cell viability assays in T-ALL and LCL cell lines treated with $5 \mathrm{Z7O}$ for 48 hours $(n=3)$. Cell viability was measured using an ATP-based cell viability assay and expressed as a percentage of the vehicle (DMSO) control. (C) IC50 values were calculated using GraphPad for 48 hours incubation. The data represent the mean and standard deviation $(n=4)$. (D) Cell viability assays comparing $5 \mathrm{Z7O}$ and JNK-IN-8 compounds in Molt3, Jurkat, and KOPT-K1 T-ALL cell lines cultured for 48 hours were measured using an ATP-based cell viability assay and expressed as a percentage of the vehicle control (DMSO). Cell viability assays were averaged from $3-4$ independent experiments. ${ }^{*} P<$ $0.05,{ }^{* *} P<0.01,{ }^{* * *} P<0.001$; two-tailed Student's $t$-test. 
pathway through immunoblots using a panel of T-ALL cell lines and LCL cells as controls. For this analysis, cells were treated with $3 \mu \mathrm{M} 5 \mathrm{Z7O}$ for 21 hours and probed for phosphorylated and total MAP2K7, JNK, and ATF2 proteins. Inhibition of MAP2K7 was evident

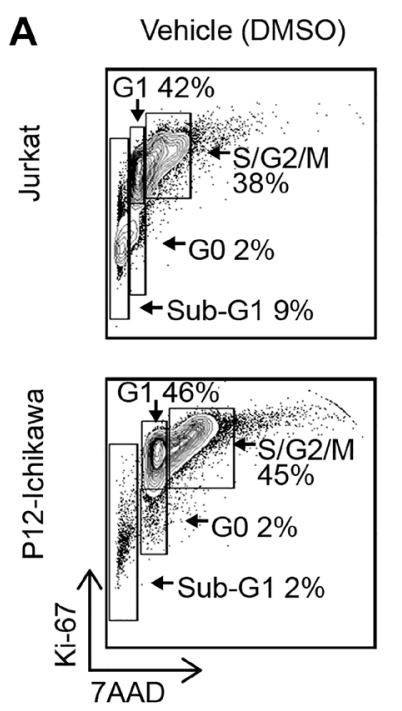
$5 Z 70($ IC50)
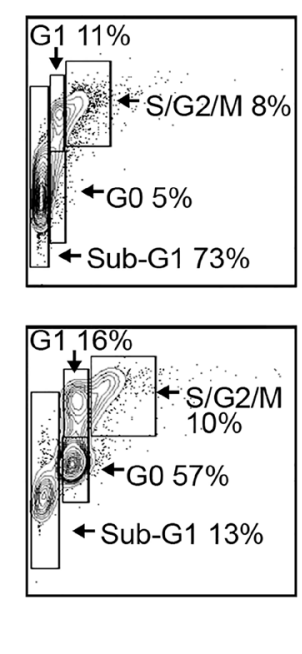

in the reduction of downstream phosphorylation of JNK and ATF2 in most T-ALL cell lines (Figure 3A); however, phosphorylation of MAP2K7 was not significantly reduced by $5 Z 7 \mathrm{O}$, suggesting that $5 \mathrm{Z7O}$ may not inhibit the kinase upstream of MAP2K7, whereas Jurkat, Molt3,
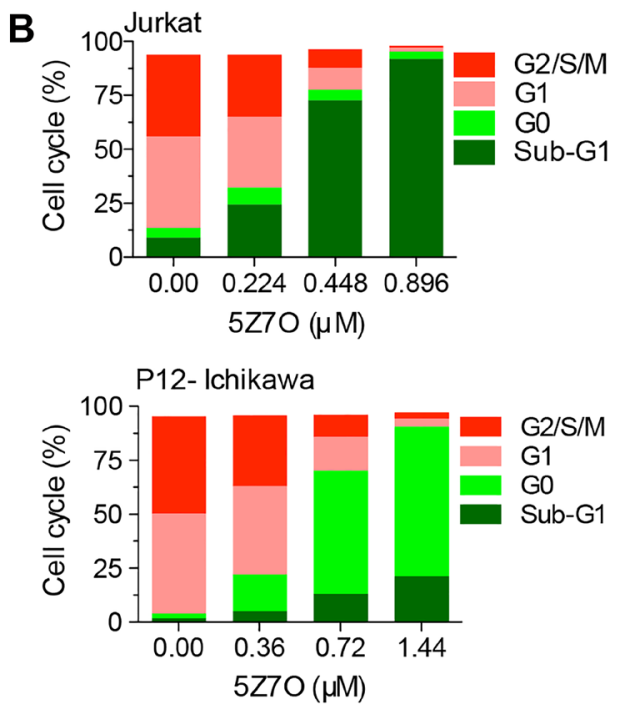

D

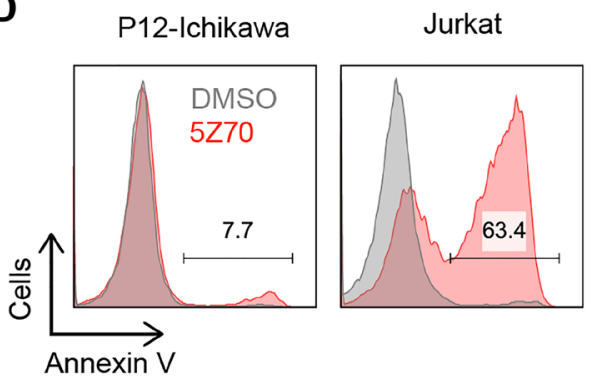

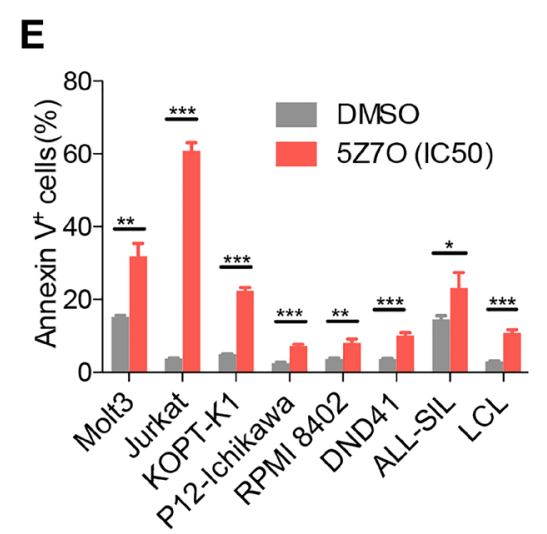
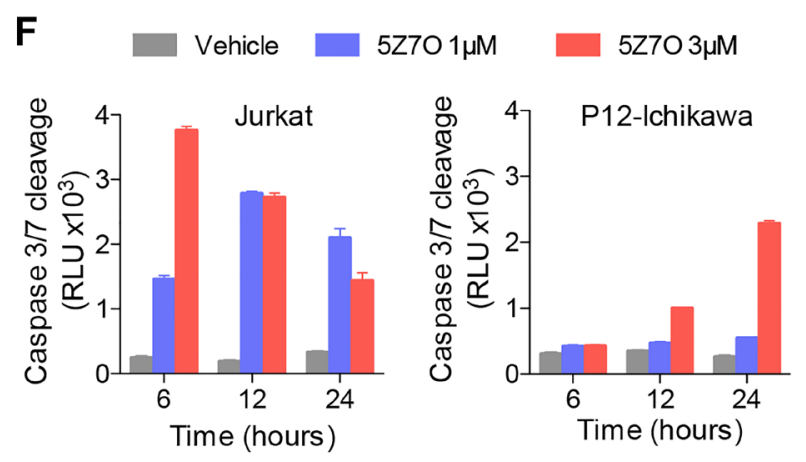

Figure 2: Treatment with $5 Z 70$ inhibits cell proliferation and induces apoptosis in T-ALL cell lines. (A) Representative flow cytometric analysis of nuclear staining of Ki67 and 7-AAD to identify proliferating cells and DNA content, respectively. (B) Cell cycle distribution as described in (A) shown for Jurkat and P12-Ichikawa cell lines treated with 5Z7O for 48 hours at IC50 concentration and concentrations below and over IC50. (C) Percentages of cells in G0-phase and sub-G1 are shown for all cell lines. Data in (C) represents average and SEM $(n=3)$. (D, E) Flow cytometry analysis of Annexin V staining in a panel of T-ALL and non-leukemic LCL cell lines following 48 hours of incubation with $5 \mathrm{Z7O}$ at the IC50 concentration $(n=3)$. (F) Time and dose dependency of $5 \mathrm{Z7O}$ induced cleavage of Caspase-3/7 in Jurkat and P12-Ichikawa cell lines $(n=3)$. Basal levels of caspase 3/7 are shown for each time point. The data represent the mean and standard deviation. ${ }^{*} P<0.05,{ }^{* *} P<0.01,{ }^{* * *} P<0.001$ (two-tailed Student's $t$-test). 
and KOPTK1 cells showed a reduction of MAP2K7 protein (Figure 3A). To ascertain whether inhibition of the downstream targets JNK and ATF2 was caused by direct inhibition of MAP2K7, we next conducted in vitro kinase assays using purified human MAP2K7 protein and dead JNK2 as substrate and two methods assaying either ATP consumption or ADP generation. 5Z7O inhibited MAP2K7 kinase activity with an IC50 value of $1.2 \mu \mathrm{M}$ (Figure 3B). Because 5Z7O can inhibit TAK1 and TAK1 could act as MAP3K upstream of MAP2K7 [20-22], we assessed whether $5 \mathrm{Z7O}$ could also inhibit TAK1 activity in a biochemical assay using TAK1-TAB1 and swine myelin basic protein (MBP) as substrate. Consistent with previous reports [22, 23], 5Z7O inhibits TAK1 activity with IC50 of $86 \mathrm{nM}$ (Figure 3C), although the absence of significant reduction in phosphorylated MAP2K7 in T-ALL cells suggests that TAK1 is not the upstream kinase. However, lower levels of phosphorylated p38 and downstream ELK1 would suggest potential inhibition of TAK1 even though ELK1 can also be targeted by JNK (Figure 3D). Because we cannot rule out TAK1 inhibition in T-ALL cells, we further supported inhibition of activated MAP2K7 using two approaches. First, we showed that $5 \mathrm{Z7O}$ can inhibit hyperactivation of MAP2K7 induced with sorbitol (Figure $3 \mathrm{E})$. Second, we retrovirally expressed the constitutively activated fusion MAP2K7-JNK2 protein in Jurkat and P12-ICHIWAKA cells, using empty retrovirus (GFP) as a control, and confirmed that $5 \mathrm{Z7O}$ inhibited activated MAP2K7 (Figure 3F). Altogether, 5Z7O induced cytotoxicity in T-ALL cell lines at least in part through inhibition of MAP2K7 and downstream JNK.

\section{Inhibition of MAP2K7 downregulates proteins of the G2/M checkpoint}

Proteomic analysis of T-ALL cell lines treated with $5 \mathrm{Z7O}$ was conducted to identify mechanisms underlying 5Z7O-mediated cytotoxicity in T-ALL cells. Cells were incubated with either vehicle (DMSO) or $5 \mathrm{Z7O}(3 \mu \mathrm{M})$ for 21 hours, a condition that showed efficient inhibition of JNK phosphorylation in all T-ALL cell lines (Supplementary Figure 2), and then processed for reverse-phase protein array (RPPA). Bioinformatic analysis revealed $5 \mathrm{Z7O}$ induced upregulation of proteins involved in apoptosis (Caspases 3,7,8) and DNA damage (pH2AX) (Figure 4A and Supplementary Figure 3). T-ALL cells sensitive to 5Z7O, such as Jurkat and Molt3, exhibited more significant deregulation than other T-ALL cell lines. On the other hand, levels of proteins involved in cell cycle regulation were significantly reduced by $5 \mathrm{Z7O}$ treatment, particularly numerous critical regulators of the G2/M cell cycle checkpoint (Figure 4A). To validate RPPA results, we confirmed by immunoblots that $5 \mathrm{Z7O}$ induced PARP cleavage, H2AX phosphorylation, and p27 expression in T-ALL cell lines while inhibiting expression of phosphorylated CDK1 (CDC2) and Cyclin B1, both key components of the G2/M checkpoint (Figure 4B). The increased levels of phosphorylated $\mathrm{H} 2 \mathrm{AX}$ were further confirmed in the nuclei of P12-Ichikawa, KOPT-K1, and RPMI-8402 cells by immunofluorescence (Figure 4C). Interestingly, our data is consistent with findings in Map $2 \mathrm{k}^{-1-}$ mouse embryonic fibroblasts of impaired proliferation, premature senescence, and downregulation of the G2/M cell-cycle kinase CDC2, a direct molecular target of the MAP2K7-JNK pathway (Figure 4D) [24]. However, our cell cycle analysis of T-ALL cells treated with $5 \mathrm{Z7O}$ did not show significant arrest at the G2/M phase of the cell cycle (Supplementary Figure 4). In addition to MAP2K7, other pathways identified as essential for T-ALL cell survival, and potential targets for drug therapy, were also inhibited by $5 \mathrm{Z7O}$ such as FOXO3, AKT, AMPK, and MEK [25-29].

\section{$5 Z 70$ inhibits the expansion of leukemic $\mathbf{T}$ cells}

The efficacy of $5 Z 70$ was further evaluated using leukemic cells from two different T-ALL mouse models. First, we generated NOTCH1-induced T-ALL based on the transformation of $K l f 4^{\mathrm{fl} / \mathrm{fl} l}$; Vav-iCre $\left(K l f 4^{\Delta / \Delta}\right)$ hematopoietic cells with retrovirus carrying either gain-of-function mutant NOTCH1 ${ }^{\mathrm{L} 1601 \mathrm{P}-\Delta \mathrm{P}}$ (leukemic) or empty retrovirus (non-leukemic) as the control followed by transplantation into cytoablated hosts $[9,30,31]$. $\mathrm{GFP}^{+}$bone marrow cells from mice transplanted with $K l f 4^{\Delta / \Delta}$ cells transduced with empty virus showed similar cytotoxicity to bone marrow cells from $K l f 4^{\mathrm{fl} / \mathrm{fl}}$ wild-type mice, whereas bone marrow cells from mice transplanted with NOTCH1 ${ }^{\mathrm{L} 1601 \mathrm{P}-}$ ${ }^{\Delta \mathrm{P}} K l f 4^{\Delta / \Delta}$ cells showed increased sensitivity (2-3-fold lower IC50) to $5 \mathrm{Z7O}$ treatment (Figure 5A). These data correlate with our previous finding that loss-of-KLF4 in NOTCH1-induced T-ALL mice exhibit aberrant activation of MAP2K7 [9]. Of note, NOTCH1 ${ }^{\text {L1601P- }}$ ${ }^{\Delta \mathrm{P}} \mathrm{Klf} 4^{\Delta / \Delta}$ bone marrow cells were collected one month after transplantation to perform the cell viability assay in parallel and therefore may contain a mixture of leukemic and polyclonal expansions with activated NOTCH1 [9]. Second, T-ALL cells from the novel $\mathrm{Kras}^{\mathrm{LSL}-\mathrm{G12D} /+} \cdot \mathrm{Mbl}^{\mathrm{Cre} /+}$ mouse model that spontaneously develops T-ALL were tested against 5Z7O [32]. Thymic cells collected from mice with full-blown T-ALL showed significantly increased sensitivity to $5 \mathrm{Z7O}$ compared to thymic cells from healthy age-matched control mice (Figure 5B). These data suggest that T-ALL cells are more sensitive to $5 Z 7 O$ irrespective of the driver mutation, which broadens potential patient application.

To evaluate whether inhibition of MAP2K7 with $5 Z 7 O$ prevents leukemia cells from expanding in vivo, we first treated KOPTK1 cells labeled with firefly luciferase (KOPTK1-Fluc) with $5 \mathrm{Z7O}$ or vehicle for three hours and transplanted the same number of viable cells to NSG mice. Bioluminescence imaging (BLI) shows a reduction in the expansion of 5Z7O-treated KOPTK1 cells compare 
to vehicle controls (Figure 5C). Before in vivo treatment, we evaluated the potential toxicity of $5 \mathrm{Z7O}(15 \mathrm{mg} /$ $\mathrm{Kg}$ ) in mice through a two-week daily intraperitoneal administration, which shows no alterations neither in body weight nor blood cell counts (Figure 5D). Finally, NSG

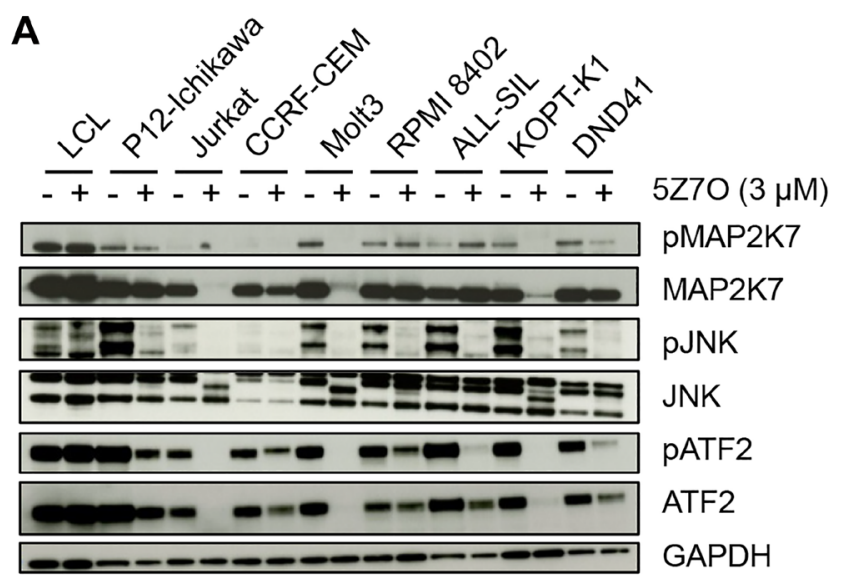

C TAK1-TAB1

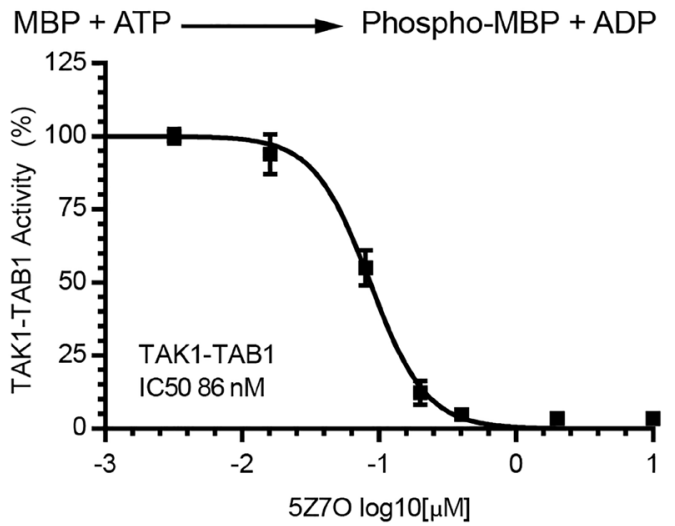

E

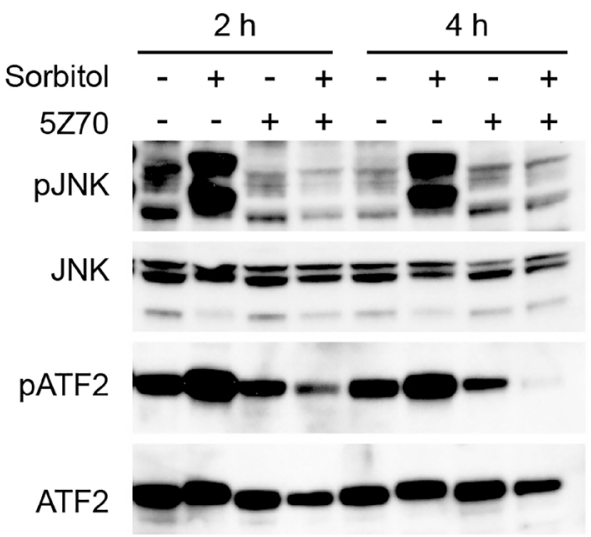

mice were injected with KOPTK1-luciferase cells and then administered with $5 \mathrm{Z} 7 \mathrm{O}$ using the regimen described above. $5 Z 7 \mathrm{O}$ treatment showed a modest inhibition of leukemic cell expansion with a slight improvement in survival (Figure 5E, 5F). This finding may suggest that

B dJNK2 + ATP $\stackrel{\text { hMAP2K7 }}{\longrightarrow}$ Phospho-dJNK2 + ADP

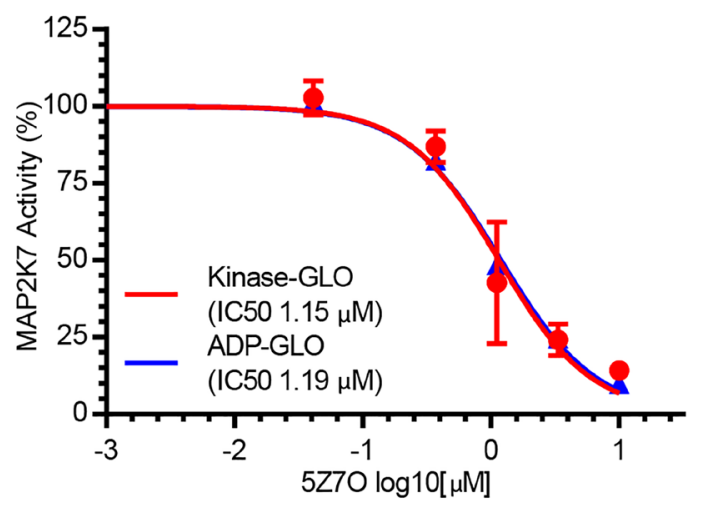

D

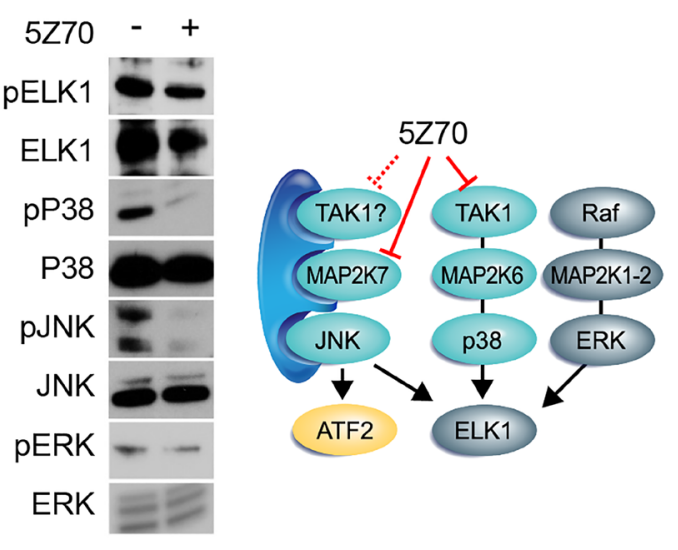

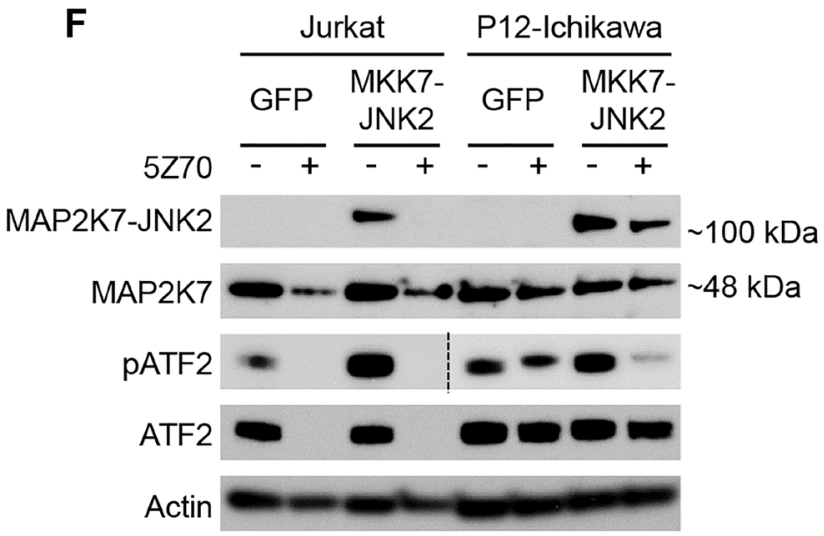

Figure 3: 5Z7O inhibits MAP2K7 activity and downstream activation of JNK. (A) Immunoblot of the MAP2K7 pathway signaling in a panel of T-ALL and non-leukemic LCL cell lines following incubation with $3 \mu \mathrm{M} 5 \mathrm{Z7O}$ for 21 hours. (B) Biochemical kinase assay using purified MAP2K7 protein, dead JNK2 substrate, and two methods of kinase activity based on ATP consumption or ADP production. (C) ADP-GLO in vitro kinase activity of purified TAK1-MBP protein following 30-minute pre-treatment with 5Z7O. (D) Immunoblot of KOPTK1 cells treated with $3 \mu \mathrm{M} 5 \mathrm{Z7O}$ to evaluate TAK1 inhibition. Diagram indicating effects of 5Z7O in the MKK signaling pathway in T-ALL cells. (E) KOPTK1 cells were treated with sorbitol to evaluate capacity of 5Z7O to inhibit activated MAP2K7. (F) Jurkat and P12-Ichikawa cells transduced with retrovirus expressing the fusion MAP2K7-JNK2 (MKK7-JNK2) protein were treated with $5 \mathrm{Z7O}$ to inhibit activated MAP2K7. For phosphorylated ATF2, immunoblot in Jurkat cells required longer exposure. 
$5 Z 70$ did not reach a therapeutic concentration to control an aggressive leukemia in this model, and therefore, more potent MAP2K7 inhibitors need to be developed for clinical translation.

\section{Anti-leukemic properties in human T-ALL}

To test the effect of MAP2K7 inhibition in T-ALL patient samples, we generated a panel of four T-ALL patient-derived xenograft (PDX) cells and evaluated sensitivity to $5 \mathrm{Z7O}$ treatment. The viability of patient T-ALL PDX cells was significantly reduced by $5 \mathrm{Z7O}$ with IC50 ranging from 1.6 to $4.0 \mu \mathrm{M}$ (Figure 6A). This is particularly important because it shows that patient samples with different cytogenetics are sensitive to pharmacological inhibition of MAP2K 7 with 5Z7O. Next, we transplanted a T-ALL PDX cell line into NSG mice and started treatment with $5 \mathrm{Z7O}$ for two weeks when

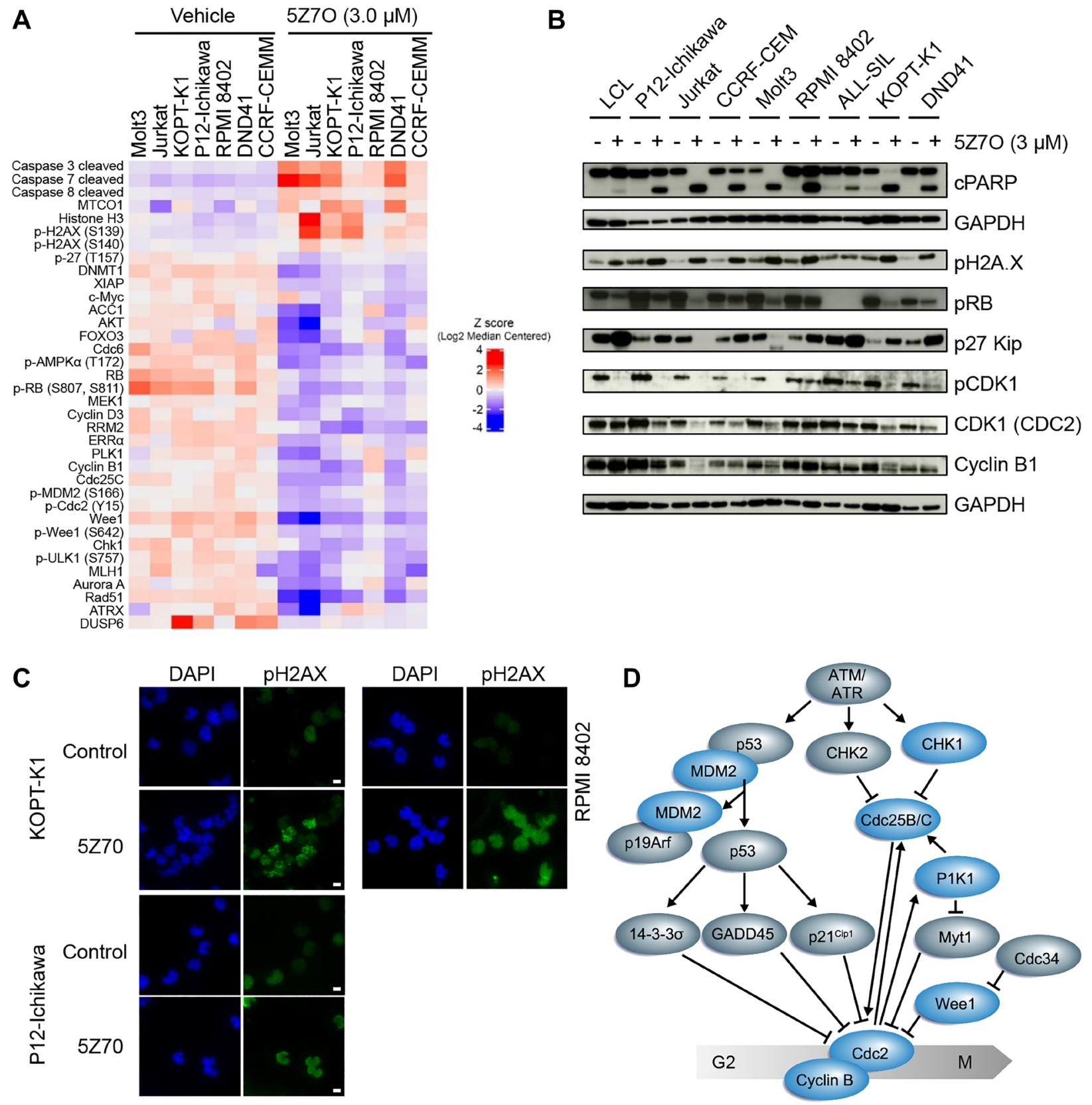

Figure 4: $5 Z 7 O$ induces activation of apoptosis pathways and disrupts cell cycle progression. (A) Supervised hierarchical clustering analysis of reverse-phase protein array (RPPA) performed in T-ALL cell lines treated with $3 \mu \mathrm{M} 5 \mathrm{Z7O}$ for 21 hours. (B) Detection of proteins involved in apoptosis and cell cycle regulation in a panel of T-ALL and non-leukemic LCL cell lines after 5Z7O treatment as described in (A). (C) Immunofluorescence detection of phosphorylated H2AX (Alexa Fluor 488) in nuclei KOPT-K1, P12-Ichikawa, and RPMI8402 cells following 5Z7O treatment. DAPI was used to detect nuclei. Scale bar: $10 \mu \mathrm{m}$. (D) Diagram of DNA damage and G2/M checkpoint. Downregulated proteins upon $5 \mathrm{Z7O}$ treatment are indicated in blue. 
A NOTCH1 161601P- $\triangle \mathrm{P}$

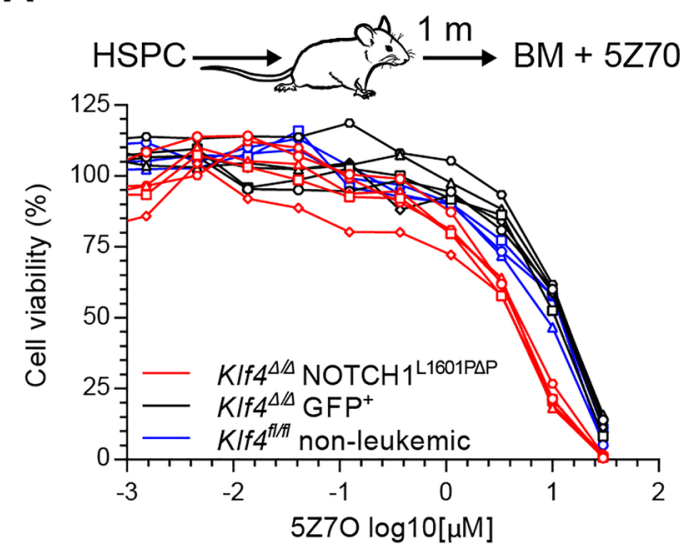

C
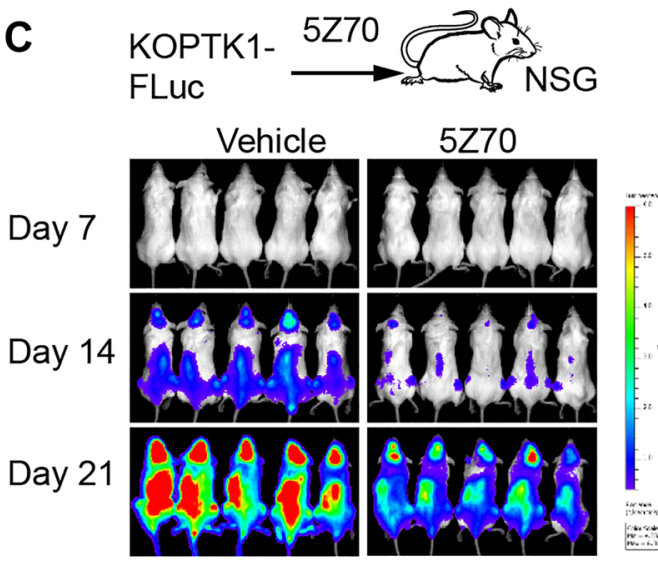

E
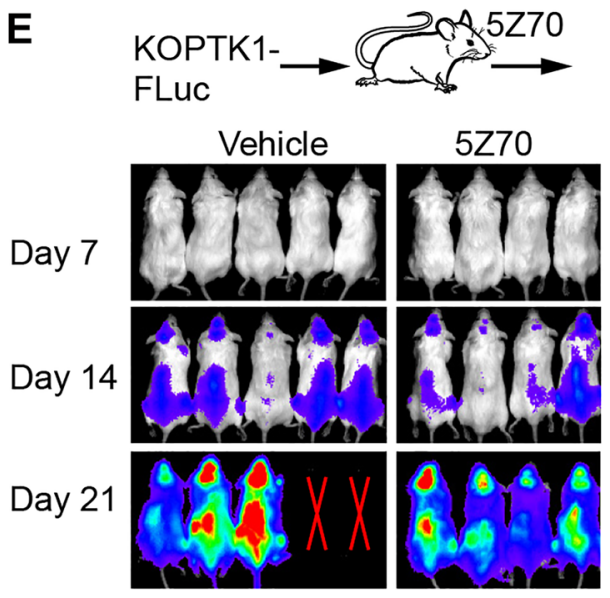

B MB1-Cre KRAS ${ }^{\mathrm{G} 12 \mathrm{D}}$
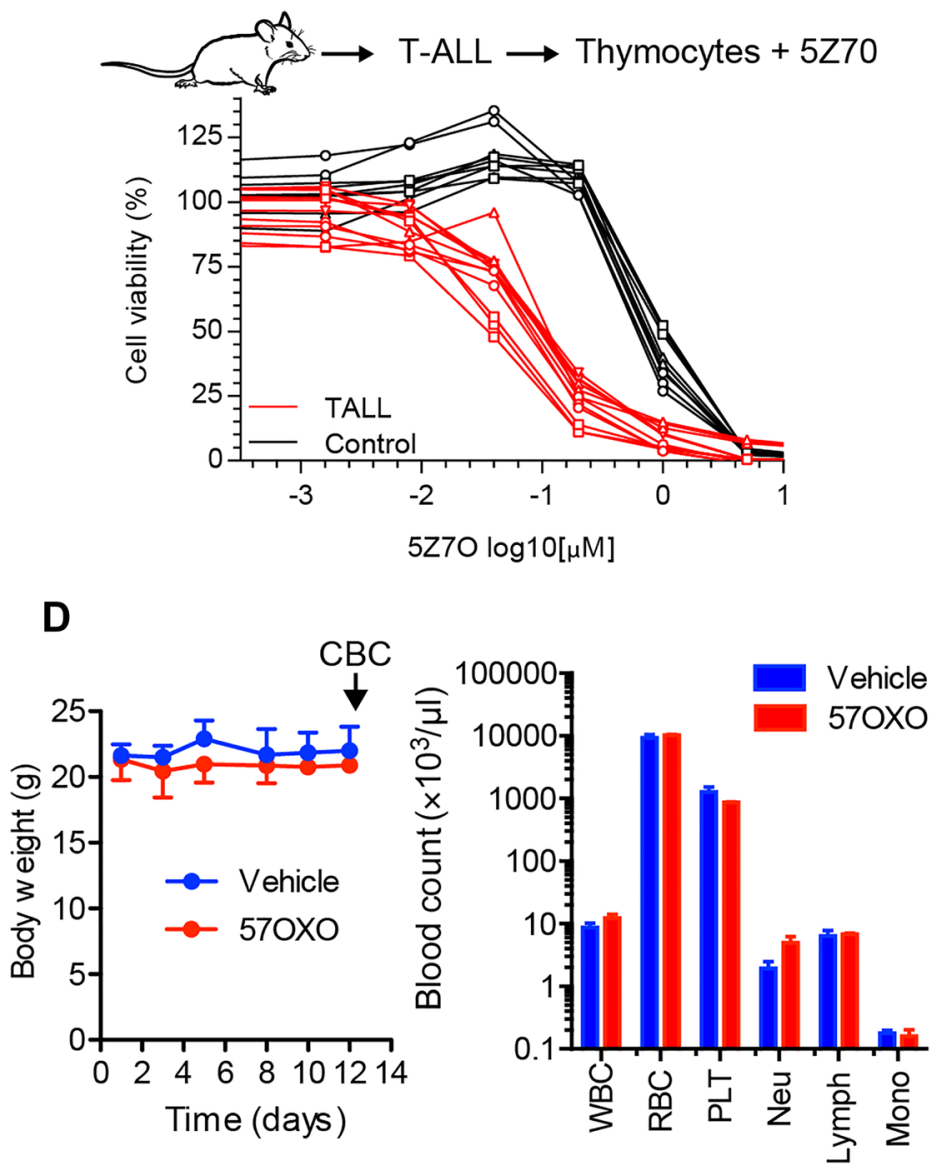

F
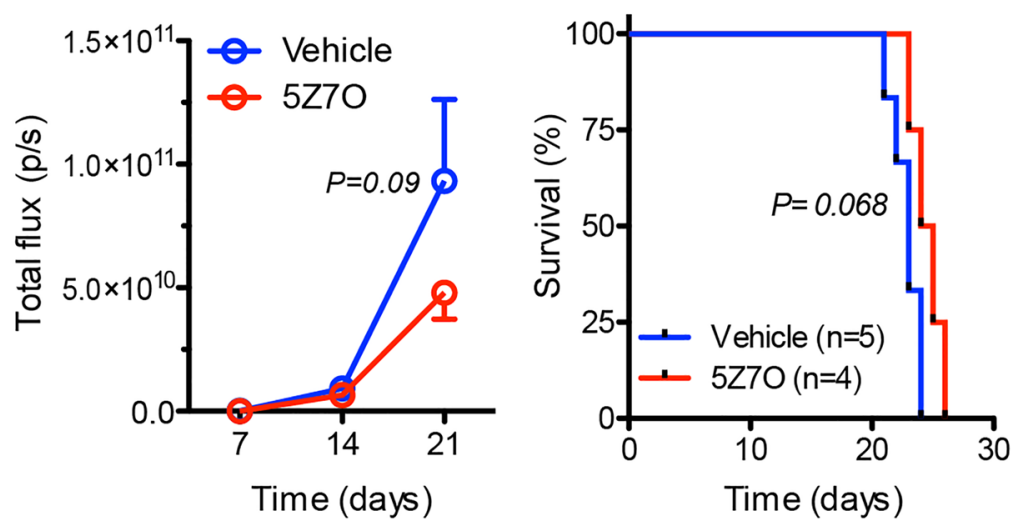

Figure 5: Leukemic cells from T-ALL mouse models are sensitivity to 5Z7O. (A) Cell viability assays of bone marrow cells

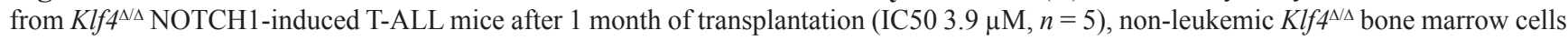
(IC50 $11.4 \mu \mathrm{M}, n=5$ ), and Klf4 ${ }^{\text {t/fl }}$ bone marrow cells (IC50 $8.7 \mu \mathrm{M}, n=3$ ). (B) Cell viability assays of thymocytes from leukemic Kras ${ }^{\mathrm{LSL}-}$ ${ }_{\mathrm{G} 12 \mathrm{D} /+} \cdot \mathrm{Mbl}^{\mathrm{Cre} / \mathrm{+}}$ mice (IC50 $83 \mathrm{nM}, n=4$ ) and age-matched controls (IC50 $956 \mathrm{nM}, n=3$ ). Cell viability was measured using an ATP-based assay and expressed as a percentage of the vehicle control (DMSO). IC50 values were calculated using GraphPad Prism. (C) KOPTK1 cells labelled with luciferase were treated in vitro with $5 \mathrm{Z7O}$ ( $3 \mu \mathrm{M}$ for 3 hours) and same number of viable cells transplanted into NSG mice ( $n=5$ per group) to monitor disease progression by bioluminescence imaging (BLI). (D) C57BL/6 mice were treated everyday Monday to Friday for two weeks with $5 \mathrm{Z7O}(15 \mathrm{mg} / \mathrm{Kg}$, intraperitoneal). Mice were monitored for body weight and blood counts to evaluate drug toxicity. (E) NSG mice ( $n=4-5$ per group) were injected with KOPTK1-luciferase cells and then administered in vivo with $5 \mathrm{Z7O}(15 \mathrm{mK} /$ $\mathrm{Kg}$ ). Mice were monitored by BLI. (F) BLI analysis and overall survival (Kaplan Meier). Data are representative of two independent experiments. $P=0.09$ (one-tailed Student's $t$-test). 
engraftment was detectable in peripheral blood and found that $5 \mathrm{Z7O}$ controlled expansion of leukemic cells during treatment (Figure 6B), although there were no significant differences in survival after discontinuing treatment (not shown). Finally, we evaluated the anti-leukemic effect of $5 \mathrm{Z7O}$ in combination with dexamethasone and etoposide, two ALL chemotherapy agents. The effect of drug combination was analyzed by calculation of combination index using CompuSyn software [33]. 5Z7O showed a synergistic anti-leukemic effect with dexamethasone in the P12-Ichikawa cell line, supporting a potential use of MAP2K7 inhibitors in the induction phase (Figure 6C, $6 \mathrm{D})$. Additionally, the combination of $5 \mathrm{Z7O}$ and etoposide produced an additive effect in Molt3 cells (Figure 6C, 6D). These findings suggest MAP2K7 inhibitors could be used in frontline, but further studies are needed to bring $5 \mathrm{Z7O}$ or other small molecules with inhibitory capacity of MAP2K 7 to the clinic.
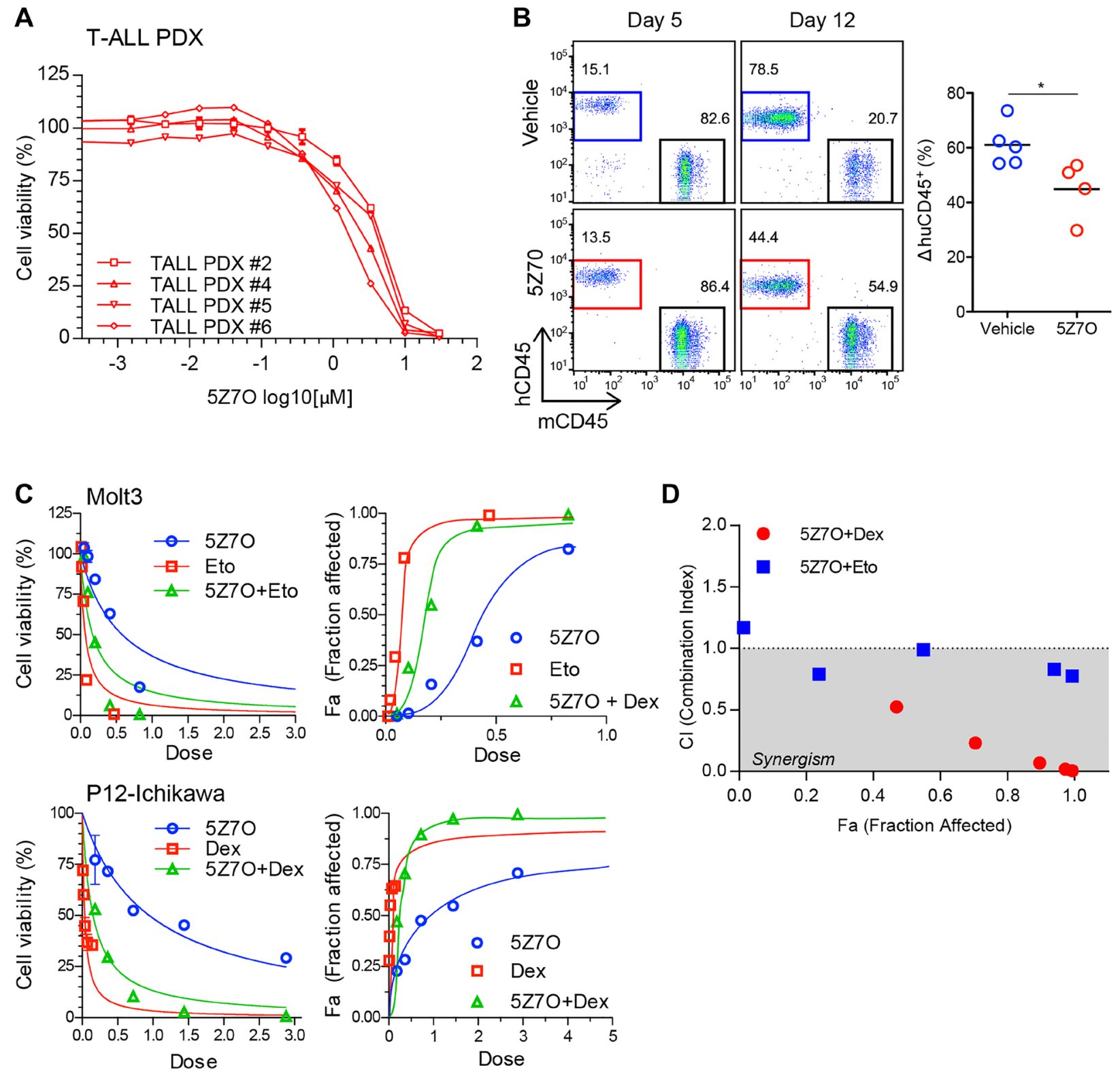

Figure 6: $5 Z 70$ is effective against human T-ALL PDXs and shows synergistic interaction with dexamethasone. (A) Cytotoxicity assays of four pediatric T-ALL PDX cells after treatment with 577 O for 48 hours (IC50s 1.6-4.0 $\mu \mathrm{M}$ ). Cell viability was measured using an ATP-based assay and expressed as a percentage of the vehicle (DMSO) control. IC50 values were calculated using GraphPad Prism. (B) T-ALL PDX cells were transplanted into NSG mice ( $n=5$ per group) and treated in vivo with $5 \mathrm{Z7O}$ ( $15 \mathrm{mg} / \mathrm{Kg}$ daily). Flow cytometric detection of human CD45 leukemic cells after 5 and 12 days of treatment. Data is representative of two independent experiments. (C) Dose response curves of $5 \mathrm{Z7O}$ in combination with dexamethasone in the P12-Ichikawa cell line and with etoposide in the Molt3 cell line. (D) Plot of combination index (CI) versus fraction affected (Fa) of $5 \mathrm{Z7O}$ combined with dexamethasone or etoposide. $\mathrm{CI}$ values were determined using CompuSyn software, $\mathrm{CI}<1.0$ corresponds to synergism, $\mathrm{CI}=1.0$ to additive effect, and $\mathrm{CI}>1.0$ to antagonism. ${ }^{*} P<0.05$ (two-tailed Student's $t$-test). 


\section{DISCUSSION}

Although most pediatric patients with ALL have a good prognosis and respond well to current drug therapy, T-ALL patients with the refractory and relapsed disease need alternative therapies able to eliminate chemoresistant leukemic cells with leukemia initiating capacity $[1,34]$. New targeted therapies and immunotherapies with success in refractory and relapsed B-ALL have not been as promising in T-ALL patients [3]. Therefore, discovering novel molecular targets is essential to improve the outlook of children with T-ALL, particularly those with clinical features associated with the worst prognosis, by advancing the development of alternative therapies.

Our group reported a novel tumor suppression function for the transcription factor KLF4 in pediatric T-ALL $[9,13]$. Both genetic loss-of-KLF4 in the NOTCH1-induced T-ALL mouse model or epigenetic KLF4 inactivation via $\mathrm{CpG}$ methylation in children with T-ALL caused aberrant activation of MAP2K 7 and the downstream target JNK $[9,14,35,36]$. Interestingly, in the T-ALL mouse model, this kinase pathway was also activated in the rare leukemia-initiating cell population, suggesting that inhibition of MAP2K 7 could potentially eradicate leukemia-initiating cells responsible for chemoresistance and relapse. JNK inhibitors were used first to target the MAP2K7 pathway because many small molecules have been studied in clinical trials for applications in inflammatory disorders and cancer [37]. The compounds CC-401 (Phase I) and orally active AS602801 (Phase II) were able to control the expansion of T-ALL patient-derived xenograft cells both in vitro and in vivo [14, 19, 38]. However, the inhibitory activity requiring micromolar concentrations made it challenging to reach therapeutic concentrations with minimal toxicity [37].

Based on these findings, direct inhibition of MAP2K7 would be a better approach to inhibit this pathway. A recent study based on crystal structure revealed a flexible inactive state of MAP2K7 that allows binding of small molecules to the ATP-binding pocket and that MAP2K 7 can be targeted with type I (active state), such as $5 \mathrm{Z7O}$, and type II (inactive state) inhibitors in reversible and irreversible fashion [39]. In this work, we investigated the anti-leukemic properties of the chemical compound $5 \mathrm{Z7O}$ because it was shown to inhibit MAP2K7 through covalent binding to cysteine 218 located in the ATP binding pocket, and $5 \mathrm{Z} 7 \mathrm{O}$ was identified in the Library of Integrated Network-based Cellular Signatures (LINCS) project as potential MAP2K7 inhibitor. The resorcylic lactone aromatic ring in $5 \mathrm{Z7O}$ resembles the adenosine ring of ATP and therefore competes with ATP binding to MAP2K7. In addition to MAP2K7, 5Z7O has been investigated as a TAK1 inhibitor in multiple disorders such as ischemic strokes, inflammatory diseases, and cancer [21, 40, 41]. Dual inhibition of MAP2K7 and TAK1 could be beneficial in T-ALL because TAK1 may act as MAP3K upstream of MAP2K7; however, lack of inhibition of MAP2K7 phosphorylation in most T-ALL cell lines suggested that $5 \mathrm{Z7O}$ cytotoxicity was mediated mainly through MAP2K7 inhibition. The synergism of 5Z7O with dexamethasone suggests the potential utility of this combination. While our primary interest lies in pediatric T-ALL, pharmacological MAP2K7 inhibition could have broader applications in other malignancies with aberrant MAP2K7 activation [8]. In fact, MAP2K7 transcripts are elevated in most cancer cell line types represented in the Cancer Cell Line Encyclopedia [42]. Colorectal cancer patients with a higher risk of liver metastases display low levels of miR-493 and elevated MAP2K7 expression [43]. In addition, lung cancer patients carrying a rare MAP2K7 p.Glu116Lys variant showed poor prognosis and increased metastases [44].

Although analysis of the human proteome indicates low levels of MAP2K7 expression in most normal tissues, including hematopoietic cells, it is important to highlight MAP2K7 physiological functions to gauge potential toxicities [45]. A limitation on the study of MAP2K 7 has been the generation of mice with embryonic Map $2 k 7$ gene deletion because of embryonic lethality stemming from defects in hepatocyte proliferation [24]. However, heterozygous Map $2 K 7$ deletion retained sufficient developmental functionality to overcome E13.5 embryonic lethality and defects associated with hepatocyte organization [24]. Interestingly and similar to the effect of $5 \mathrm{Z7O}$ in T-ALL cell lines, Map $2 \mathrm{k}^{-/-}$hepatoblasts showed diminished levels of the cdc2 protein involved in the G2/M phase of the cell cycle [24]. Deleting MAP2K4, another MAP2K kinase that phosphorylates JNK, results in a similar defect in hepatogenesis, indicating that JNK activity is driving liver development [46]. JNK activity is increased in immature double positive thymocytes, presumably mediated via MAP2K7, and involved in the negative selection of immature thymocytes [47]. MAP2K7 inhibition may have an anti-inflammatory role because peripheral $\mathrm{T}$ cells activate signaling pathways downstream of TCR, including MAP2K7. Collectively, these findings suggest pharmacological inhibition of MAP2K7 is expected to have a minimal deleterious effect on adult tissue homeostasis and warrants further preclinical studies.

In summary, we provide proof-of-principle data in support of targeting the MAP2K7 pathway in pediatric T-ALL. The chemical $5 Z 70$ shows selectivity to MAP2K7 and induces dose-dependent apoptosis and deregulation of the cell cycle in murine T-ALL models, established cell lines, and human patient-derived xenografts. The low efficacy observed in in vivo treatment suggests that more research is needed to develop small molecules with increased potency and specificity relative to MAP2K7 and evaluate their capacity to eradicate chemoresistant leukemia-initiating cells in T-ALL patients. 


\section{MATERIALS AND METHODS}

\section{Chemical treatment of T-ALL cell lines}

The following cell lines were cultured in RPMI1640 medium supplemented with $10 \%$ fetal bovine serum: Molt3, Jurkat, KOPT-K1, P12-Ichikawa, DND41, RPMI-8402, ALL-SIL, CCRF-CEM, and LCL (an EBVtransformed lymphoblastoid cell line). 5Z-7-oxozeaenol (5Z7O) was purchased from Tocris (Cat. \#3604), dissolved in DMSO to a stock concentration of $25 \mathrm{mM}$, and stored at $-20^{\circ} \mathrm{C}$. Cells were treated with different concentrations of $5 \mathrm{Z7O}$ for 24 and 48 hours. Cells were tested regularly for mycoplasma and authenticated using STR fingerprinting every 6 months.

\section{Cell viability assay}

$5 \mathrm{Z7O}$ was diluted from stock to specified concentrations in RPMI-1640 cell culture medium supplemented with $10 \%$ fetal bovine serum. The vehicle control condition contained an equivalent concentration of DMSO $(<0.5 \%)$. Cell lines were plated in triplicate at a cell density of $2 \times 10^{4}$ cells per well (96-well plate) in the presence or absence of $5 \mathrm{Z7O}$ (from $1.5 \mathrm{nM}$ to $30 \mu \mathrm{M}$ ) for 48 hours. Cell viability was measured using CellTiterGlo Luminescent cell viability assay. Curve fitting and statistics, including half-maximal inhibitory concentration (IC50), were calculated using Prism GraphPad nonlinear regression.

\section{Apoptosis and cell cycle analysis}

Cells treated with a specified concentration of $5 \mathrm{Z7O}$ or vehicle for 48 hours and then assayed for apoptosis and cell cycle progression. Apoptosis detection was performed using PE Annexin V apoptosis detection kit (Becton-Dickinson \#559763). Cells were treated with fixation/permeabilization solution kit (Becton-Dickinson \#554714) before staining with antiKi-67 FITC (Thermo Fisher \#11-5698-82) and 7AAD for cell proliferation and DNA content, respectively. Flow cytometry analysis was conducted using FACS Canto (Becton-Dickinson Bioscience) and FlowJo software (TriStar).

\section{Caspases-3/7 activity assay}

Jurkat and P12-Ichikawa cells were plated at a cell density of $2 \times 10^{4}$ cells per well (96-well plate) in the presence of $1 \mu \mathrm{M}$ or $3 \mu \mathrm{M} 5 \mathrm{Z7O}$. At 6,12 , and 24 hours, the Caspase-GLO 3/7 Assay System (Promega G8091) was used to evaluate caspase activity resulting from $5 \mathrm{Z7O}$ treatment. Luminescence values corresponding to caspase- 3 and caspase- 7 cleavage were plotted using Prism GraphPad.

\section{In vitro kinase assay}

Purified human MAP2K7 (Origene) or TAK1TAB protein (Promega V4088) was plated with the corresponding substrate (dead JNK2 fragment for MAP2K 7 and Myelin Basic Protein for TAK1) along with vehicle (DMSO) or $5 \mathrm{Z7O}$. TAK1-TAB1 is used because TAK1-binding protein (TAB) is required to allow ATP binding and the fusion TAK1-TAB1 is constitutively active [48]. After preincubation for 30 minutes, ATP was added to initiate kinase activity for 30 minutes. The resulting enzymatic activity was measured through consumption of ATP (Kinase-GLO ${ }^{\circledR}$ Plus Kinase Assay System, Promega \#V3771) or generation of ADP (ADP-GLO, Promega \#V6930). Luminescence values were calculated as the percentage of vehicle treated control. The plot, non-linear curve fit, and IC50 calculations were conducted using Prism GraphPad.

\section{Immunoblot analysis}

After 21 hours of $5 \mathrm{Z7O}$ treatment at specified concentrations, cells were lysed with SDS lysis buffer containing (10 mM Tris pH 7.4 containing $1 \%$ SDS and $1 \mathrm{mM}$ PMSF) and supplemented with Halt Protease and Phosphatase Inhibitor Cocktail (Thermo Fisher). Protein lysates were electrophoresed onto SDS PAGE gel before transferred to the PVDF membrane for blocking, antibody probing, and developing. Antibodies corresponding to the following target proteins were used at 1:1000 dilution: phospho-MKK7 (\#4171), MKK7 (\#4172), phosphoSAPK/JNK (clone 81E11) (\#4668), SAPK/JNK (\#9252), phospho-ATF2 (\#15411), ATF2 (\#9226), PARP (\#9542, 1:10,000 dilution), phospho-H2A.X (\#9719), phospho-RB (\#3590), p27-Kip (\#3686), phospho-Cdc2 (\#9111), Cdc2 (\#9112), and Cyclin B1 (\#4138). Secondary antibodies cross-linked with HRP (anti-rabbit IgG \#7074 and antimouse IgG \#7076) were used for respective primary antibodies at concentrations $1: 20,000$ to $1: 50,000$. Protein detection was performed using West Femto Maximum Sensitivity Substrate (Thermo Fisher) and Amersham Hyperfilm ECL (GE).

\section{Activation of MAP2K7 in T-ALL cell lines}

KOPT-K1 cells were treated with $400 \mathrm{mM}$ sorbitol for 30 minutes, and then $5 \mathrm{Z} 7 \mathrm{O}(10 \mu \mathrm{M})$ was added for 2 or 4 hours, followed by cell lysis for immunoblot analysis. Jurkat and P12-Ichikawa cells were transduced with either MSCV(IRES-GFP) retroviral vector containing the MAP2K7-JNK2 fusion protein or empty vector as a control (GFP). Transduced cells were sorted using BD FACSAria II cell sorter to purify GFP positive cells. Sorted cells were expanded and treated with vehicle or $5 \mathrm{Z7O}(3 \mu \mathrm{M})$ for 21 hours, followed by cell lysis for immunoblot analysis. 


\section{Reverse-phase protein array}

After 21 hours of culture with vehicle (DMSO) or $3 \mu \mathrm{M} 5 \mathrm{Z7O}$, T-ALL cells were submitted frozen to the MD Anderson Cancer Center's Reverse Phase Protein Array Core where protein lysate was prepared for hybridization of arrays. ComplexHeatmap R package was used to generate heatmap [49]. Differential analysis was performed using Linear Models of Microarray Data (R Package) [50].

\section{Immunofluorescence}

RPMI-8402, KOPT-K1, and P12-Ichikawa cells were treated with $3 \mu \mathrm{M} 5 \mathrm{Z7O}$ for either 6 or 21 hours. Cells were spun onto slides using a cytocentrifuge and then fixed with acetone. After incubation with blocking buffer (PBS $0.3 \%$ Triton-X100 with 5\% normal goat serum), phospho-histone H2A.X primary antibody (1:50 dilution, Cell Signaling \#2577) was added to each slide and incubated overnight at $4^{\circ} \mathrm{C}$. After washing, Alexa Fluor 488 conjugated anti-Rabbit IgG secondary antibody (1:500 dilution) was added to each slide and incubated for 2 hours. After washing, ProLong Gold antifade mounting solution with DAPI (Invitrogen \#P36935) was applied to each slide before covering it with coverslip. All images were captured with ECLIPSE 90i Nikon fluorescence microscope at $100 \times$ lens with oil.

\section{NOTCH1 gain-of-function mutant induction of T-ALL mouse model}

Bone marrow cells were obtained from femur and tibia from $\mathrm{Klf}_{\mathrm{fl}}^{\mathrm{flfl}} \mathrm{Vav}$-iCre mice four days after intraperitoneal injection of 5-fluorouracil $(150 \mathrm{mg} / \mathrm{kg})$. After 48-hour culture in X-Vivo15 supplemented with murine stem cell factor $(100 \mathrm{ng} / \mathrm{mL}), \mathrm{IL}-3(6 \mathrm{ng} / \mathrm{mL})$, IL-6 $(10 \mathrm{ng} / \mathrm{mL})$, hematopoietic stem/progenitor cells were transduced twice with retroviral supernatant containing MIGR1-NOTCH1-L1601P- $\Delta$ P. Following 48 hours of culture, the transduced cells $\left(0.5 \times 10^{6}\right.$ cells per mouse $)$ were transplanted into lethally irradiated C57BL/6J mice (950 Rads). Leukemic cell expansion was monitored in peripheral blood through a flow cytometric analysis panel consisting of GFP, CD4, and CD8. Four weeks after transplantation, bone marrow was isolated from the femur of leukemic and non-leukemic mice for in vitro treatment with $5 \mathrm{Z7O}$.

\section{Patient samples}

T-ALL diagnostic bone marrow samples were obtained with consent from patients treated at Texas Children's Cancer and Hematology Center under an Institutional Review Board approved protocol and transplanted $\left(0.5-1.0 \times 10^{6}\right.$ cells/mouse) into 10 -week-old female NSG mice that had received 200 Rads irradiation. Peripheral blood sampled from the tail vein was routinely monitored for human CD45 positive cells via flow cytometry. Human leukemic cells were collected from femur and tibia and spleen, examined for expression of human CD45 surface antigen, and either frozen or treated with $5 \mathrm{Z7O}$ according to cell line viability assay using X-Vivo15 media supplemented with IL-7 (10 ng/mL).

\section{In vivo studies of $5 \mathrm{Z7O}$}

To evaluate toxicity, $5 \mathrm{Z7O}$ prepared in $10 \%$ DMSO and $90 \%$ corn oil $(15 \mathrm{mg} / \mathrm{Kg})$ was administered intraperitoneally every day from Monday to Friday for two weeks and mice were monitored for body weight and complete blood counts. First, NSG mice were transplanted with KOPTK1-FLuc cells $\left(2.5 \times 10^{5}\right)$ previously treated with $57 \mathrm{Z} 0(3 \mu \mathrm{M}$ for 3 hours $)$ and monitored for BLI. Next, NSG mice were transplanted with KOPTK-1 cells labeled with firefly luciferase $\left(2.5 \times 10^{5}\right)$ and treated for three weeks with $5 \mathrm{Z} 7 \mathrm{O}$ or vehicle using the same dose and administration plan as toxicity experiment and evaluated by bioluminescence at the end of each week. For bioluminescence detection, the images were acquired in anesthetized mice using the IVIS Imaging System (Xenogen) 10 minutes after intraperitoneal injection with $50 \mathrm{mg} / \mathrm{kg}$ D-luciferin. Finally, NSG mice were injected with T-ALL PDX cells $\left(1 \times 10^{6}\right)$ and randomized a week later into two groups (administration of vehicle or $15 \mathrm{mg} / \mathrm{Kg} 5 \mathrm{Z7O}$ ) and monitored for expansion of human CD45 positive cells in peripheral blood by flow cytometry.

\section{Statistics}

All sample sizes ( $n$ values) indicated in each figure legend correspond to independent biological replicates. Experimental results with more than 8 values were confirmed to follow normal distribution by the D'Agostino-Pearson normality test, and no significant differences in the variance between groups were detected using the F test (Prism Graphpad). Unpaired two-tailed Student's $t$-test was used for statistical analysis. $P$ values were determined using GraphPad software. Results with a $P$ value $<0.05$ were considered statistically significant.

\section{Abbreviations}

T-ALL: T-cell acute lymphoblastic leukemia; KLF4: Krüppel-like factor 4; MAP2K7: mitogenactivated kinase kinase 7; MAP2K4: mitogen-activated kinase kinase 4; 5Z7O: 5Z-7-Oxozeaenol; JNK: c-Jun $\mathrm{N}$-terminal kinase; BLI: bioluminescence imaging; NSG: NOD scid gamma mouse; PDX: patient-derived xenograft; RPPA: reverse phase protein array; ATF2: activating transcription factor 2 . 


\section{Author contributions}

TJC designed and performed experiments, interpreted the data, and wrote the manuscript. WD contributed to immunohistochemistry and bioinformatic analysis. CSB, YS, MP performed experiments. JJJ and KRR performed cytotoxicity assays in the mouse model. HDL conceived, directed, and funded the project as the principal investigator.

\section{ACKNOWLEDGMENTS AND FUNDING}

The authors thank Karen Prince for the preparation of figures. This work was supported by the National Cancer Institute to H.D.L. (RO1 CA207086-01A1), the ASH Bridge Award to H.D.L, the National Institute of General Medical Sciences T32, National Institutes of Health (GM008231) to T.C., the Cytometry and Cell Sorting Core at Baylor College of Medicine (P30 AI036211, P30 CA125123, and S10 RR024574) and the Flow Cytometry Core at Texas Children's Cancer and Hematology Center (S10 OD020066).

\section{CONFLICTS OF INTEREST}

Authors have no conflicts of interest to declare.

\section{REFERENCES}

1. Pui CH, Robison LL, Look AT. Acute lymphoblastic leukaemia. Lancet. 2008; 371:1030-43. https://doi. org/10.1016/S0140-6736(08)60457-2. [PubMed]

2. Siegel DA, Henley SJ, Li J, Pollack LA, Van Dyne EA, White A. Rates and Trends of Pediatric Acute Lymphoblastic Leukemia - United States, 2001-2014. MMWR Morb Mortal Wkly Rep. 2017; 66:950-54. https:// doi.org/10.15585/mmwr.mm6636a3. [PubMed]

3. Teachey DT, Pui CH. Comparative features and outcomes between paediatric T-cell and B-cell acute lymphoblastic leukaemia. Lancet Oncol. 2019; 20:e142-54. https://doi. org/10.1016/S1470-2045(19)30031-2. [PubMed]

4. Pui CH, Carroll WL, Meshinchi S, Arceci RJ. Biology, risk stratification, and therapy of pediatric acute leukemias: an update. J Clin Oncol. 2011; 29:551-65. https://doi. org/10.1200/JCO.2010.30.7405. [PubMed]

5. Pui $\mathrm{CH}$, Evans WE. Treatment of acute lymphoblastic leukemia. N Engl J Med. 2006; 354:166-78. https://doi. org/10.1056/NEJMra052603. [PubMed]

6. Iacobucci I, Mullighan CG. Genetic Basis of Acute Lymphoblastic Leukemia. J Clin Oncol. 2017; 35:975-83. https://doi.org/10.1200/JCO.2016.70.7836. [PubMed]

7. Ko RH, Ji L, Barnette P, Bostrom B, Hutchinson R, Raetz E, Seibel NL, Twist CJ, Eckroth E, Sposto R, Gaynon PS, Loh ML. Outcome of patients treated for relapsed or refractory acute lymphoblastic leukemia: a Therapeutic Advances in Childhood Leukemia Consortium study. J Clin Oncol. 2010; 28:648-54. $\quad$ https://doi.org/10.1200/JCO.2009.22.2950. [PubMed]

8. Park JG, Aziz N, Cho JY. MKK7, the essential regulator of JNK signaling involved in cancer cell survival: a newly emerging anticancer therapeutic target. Ther Adv Med Oncol. 2019; 11:1758835919875574. https://doi. org/10.1177/1758835919875574. [PubMed]

9. Shen Y, Park CS, Suppipat K, Mistretta TA, Puppi M, Horton TM, Rabin K, Gray NS, Meijerink JPP, Lacorazza HD. Inactivation of KLF4 promotes T-cell acute lymphoblastic leukemia and activates the MAP2K7 pathway. Leukemia. 2017; 31:1314-24. https://doi. org/10.1038/leu.2016.339. [ubMed]

10. Yamada T, Park CS, Mamonkin M, Lacorazza HD. Transcription factor ELF4 controls the proliferation and homing of CD8+ T cells via the Krüppel-like factors KLF4 and KLF2. Nat Immunol. 2009; 10:618-26. https://doi. org/10.1038/ni.1730. [PubMed]

11. Park CS, Lewis A, Chen T, Lacorazza D. Concise Review: Regulation of Self-Renewal in Normal and Malignant Hematopoietic Stem Cells by Krüppel-Like Factor 4. Stem Cells Transl Med. 2019; 8:568-74. https://doi.org/10.1002/ sctm.18-0249. [PubMed]

12. Park CS, Shen Y, Lewis A, Lacorazza HD. Role of the reprogramming factor KLF4 in blood formation. J Leukoc Biol. 2016; 99:673-85. https://doi.org/10.1189/ jlb.1RU1215-539R. [PubMed]

13. Shen Y, Chen TJ, Lacorazza HD. Novel tumor-suppressor function of KLF4 in pediatric T-cell acute lymphoblastic leukemia. Exp Hematol. 2017; 53:16-25. https://doi. org/10.1016/j.exphem.2017.04.009. [PubMed]

14. Lacorazza HD. KLF4 represses MAP2K7 signaling in T-ALL. Oncotarget. 2017; 8:73366-67. https://doi. org/10.18632/oncotarget.20672. [PubMed]

15. Sasaki T, Wada T, Kishimoto H, Irie-Sasaki J, Matsumoto G, Goto T, Yao Z, Wakeham A, Mak TW, Suzuki A, Cho SK, Zuniga-Pflucker JC, Oliveira-dosSantos AJ, et al. The stress kinase mitogen-activated protein kinase kinase (MKK)7 is a negative regulator of antigen receptor and growth factor receptor-induced proliferation in hematopoietic cells. J Exp Med. 2001; 194:757-68. $\quad$ https://doi.org/10.1084/jem.194.6.757. [PubMed]

16. Kwong AJ, Scheidt KA. Non-'classical' MEKs: A review of MEK3-7 inhibitors. Bioorg Med Chem Lett. 2020; 30:127203. https://doi.org/10.1016/j.bmcl.2020.127203. [PubMed]

17. Deibler KK, Mishra RK, Clutter MR, Antanasijevic A, Bergan R, Caffrey M, Scheidt KA. A Chemical Probe Strategy for Interrogating Inhibitor Selectivity Across the MEK Kinase Family. ACS Chem Biol. 2017; 12:1245-56. https://doi.org/10.1021/acschembio.6b01060. [PubMed] 
18. Sogabe $Y$, Matsumoto $T$, Hashimoto T, Kirii Y, Sawa M, Kinoshita T. 5Z-7-Oxozeaenol covalently binds to MAP2K7 at Cys218 in an unprecedented manner. Bioorg Med Chem Lett. 2015; 25:593-96. https://doi.org/10.1016/j. bmcl.2014.12.011. [PubMed]

19. Zhang T, Inesta-Vaquera F, Niepel M, Zhang J, Ficarro SB, Machleidt T, Xie T, Marto JA, Kim N, Sim T, Laughlin JD, Park H, LoGrasso PV, et al. Discovery of potent and selective covalent inhibitors of JNK. Chem Biol. 2012; 19:140-54. https://doi.org/10.1016/j.chembiol.2011.11.010. [PubMed]

20. Cao H, Lu J, Du J, Xia F, Wei S, Liu X, Liu T, Liu Y, Xiang M. TAK1 inhibition prevents the development of autoimmune diabetes in NOD mice. Sci Rep. 2015; 5:14593. https://doi.org/10.1038/srep14593. [PubMed]

21. Lu L, Zhang X, Tong H, Zhang W, Xu P, Qu S. Central Administration of 5Z-7-Oxozeaenol Protects Experimental Autoimmune Encephalomyelitis Mice by Inhibiting Microglia Activation. Front Pharmacol. 2017; 8:789. https:// doi.org/10.3389/fphar.2017.00789. [PubMed]

22. Wu J, Powell F, Larsen NA, Lai Z, Byth KF, Read J, Gu RF, Roth M, Toader D, Saeh JC, Chen H. Mechanism and in vitro pharmacology of TAK1 inhibition by (5Z)-7Oxozeaenol. ACS Chem Biol. 2013; 8:643-50. https://doi. org/10.1021/cb3005897. [PubMed]

23. Ninomiya-Tsuji J, Kajino T, Ono K, Ohtomo T, Matsumoto M, Shiina M, Mihara M, Tsuchiya M, Matsumoto K. A resorcylic acid lactone, 5Z-7-oxozeaenol, prevents inflammation by inhibiting the catalytic activity of TAK1 MAPK kinase kinase. J Biol Chem. 2003; 278:18485-90. https://doi.org/10.1074/jbc.M207453200. [PubMed]

24. Wada T, Joza N, Cheng HY, Sasaki T, Kozieradzki I, Bachmaier K, Katada T, Schreiber M, Wagner EF, Nishina $\mathrm{H}$, Penninger JM. MKK7 couples stress signalling to G2/M cell-cycle progression and cellular senescence. Nat Cell Biol. 2004; 6:215-26. https://doi.org/10.1038/ncb1098. [PubMed]

25. Hua C, Guo H, Bu J, Zhou M, Cheng H, He F, Wang J, Wang X, Zhang Y, Wang Q, Zhou J, Cheng T, Xu M, Yuan W. Rictor/mammalian target of rapamycin 2 regulates the development of Notch1 induced murine T-cell acute lymphoblastic leukemia via forkhead box O3. Exp Hematol. 2014; 42:1031-40.e1-4. https://doi.org/10.1016/j. exphem.2014.08.006. [PubMed]

26. Palomero T, Dominguez M, Ferrando AA. The role of the PTEN/AKT Pathway in NOTCH1-induced leukemia. Cell Cycle. 2008; 7:965-70. https://doi.org/10.4161/cc.7.8.5753. [PubMed]

27. Piovan E, Yu J, Tosello V, Herranz D, Ambesi-Impiombato A, Da Silva AC, Sanchez-Martin M, Perez-Garcia A, Rigo I, Castillo M, Indraccolo S, Cross JR, de Stanchina E, et al. Direct reversal of glucocorticoid resistance by AKT inhibition in acute lymphoblastic leukemia. Cancer Cell. 2013; 24:766-76. https://doi.org/10.1016/j.ccr.2013.10.022. [PubMed]
28. Kishton RJ, Barnes CE, Nichols AG, Cohen S, Gerriets VA, Siska PJ, Macintyre AN, Goraksha-Hicks P, de Cubas AA, Liu T, Warmoes MO, Abel ED, Yeoh AE, et al. AMPK Is Essential to Balance Glycolysis and Mitochondrial Metabolism to Control T-ALL Cell Stress and Survival. Cell Metab. 2016; 23:649-62. https://doi.org/10.1016/j. cmet.2016.03.008. [PubMed]

29. Canté-Barrett K, Spijkers-Hagelstein JA, Buijs-Gladdines JG, Uitdehaag JC, Smits WK, van der Zwet J, Buijsman RC, Zaman GJ, Pieters R, Meijerink JP. MEK and PI3KAKT inhibitors synergistically block activated IL7 receptor signaling in T-cell acute lymphoblastic leukemia. Leukemia. 2016; 30:1832-43. https://doi.org/10.1038/leu.2016.83. [PubMed]

30. Chiang MY, Xu L, Shestova O, Histen G, L'heureux S, Romany C, Childs ME, Gimotty PA, Aster JC, Pear WS. Leukemia-associated NOTCH1 alleles are weak tumor initiators but accelerate K-ras-initiated leukemia. J Clin Invest. 2008; 118:3181-94. https://doi.org/10.1172/JCI35090. [PubMed]

31. Liu H, Chiang MY, Pear WS. Critical roles of NOTCH1 in acute T-cell lymphoblastic leukemia. Int J Hematol. 2011; 94:118-25. https://doi.org/10.1007/s12185-011-0899-3. [PubMed]

32. Junco JJ, Chen T, Rashid R, Terrell M, Gant VU Jr, Miller M, Rau R, Lacorazza HD, Rabin KR. An Mb1-Cre-driven oncogenic Kras mutation results in a mouse model of T-acute lymphoblastic leukemia/lymphoma with short latency and high penetrance. Leukemia. 2021; 35:1777-81. https://doi.org/10.1038/s41375-020-01036-w. [PubMed]

33. Chou TC, Talalay P. Quantitative analysis of dose-effect relationships: the combined effects of multiple drugs or enzyme inhibitors. Adv Enzyme Regul. 1984; 22:27-55. https://doi.org/10.1016/0065-2571(84)90007-4. [PubMed]

34. Pui CH, Pei D, Campana D, Cheng C, Sandlund JT, Bowman WP, Hudson MM, Ribeiro RC, Raimondi SC, Jeha S, Howard SC, Bhojwani D, Inaba H, et al. A revised definition for cure of childhood acute lymphoblastic leukemia. Leukemia. 2014; 28:2336-43. https://doi. org/10.1038/leu.2014.142. [PubMed]

35. Homminga I, Pieters R, Langerak AW, de Rooi JJ, Stubbs A, Verstegen M, Vuerhard M, Buijs-Gladdines J, Kooi C, Klous P, van Vlierberghe P, Ferrando AA, Cayuela $\mathrm{JM}$, et al. Integrated transcript and genome analyses reveal NKX2-1 and MEF2C as potential oncogenes in T cell acute lymphoblastic leukemia. Cancer Cell. 2011; 19:484-97. https://doi.org/10.1016/j.ccr.2011.02.008. [PubMed]

36. Haeusgen W, Herdegen T, Waetzig V. The bottleneck of JNK signaling: molecular and functional characteristics of MKK4 and MKK7. Eur J Cell Biol. 2011; 90:536-44. https://doi.org/10.1016/j.ejcb.2010.11.008. [PubMed]

37. Manning AM, Davis RJ. Targeting JNK for therapeutic benefit: from junk to gold? Nat Rev Drug Discov. 2003; 2:554-65. https://doi.org/10.1038/nrd1132. [ [PubMed] 
38. Bennett BL, Sasaki DT, Murray BW, O’Leary EC, Sakata ST, Xu W, Leisten JC, Motiwala A, Pierce S, Satoh Y, Bhagwat SS, Manning AM, Anderson DW. SP600125, an anthrapyrazolone inhibitor of Jun N-terminal kinase. Proc Natl Acad Sci U S A. 2001; 98:13681-86. https://doi. org/10.1073/pnas.251194298. [PubMed]

39. Schröder M, Tan L, Wang J, Liang Y, Gray NS, Knapp S, Chaikuad A. Catalytic Domain Plasticity of MKK7 Reveals Structural Mechanisms of Allosteric Activation and Diverse Targeting Opportunities. Cell Chem Biol. 2020; 27:128595.e4. https://doi.org/10.1016/j.chembiol.2020.07.014. [PubMed]

40. Guan S, Lu J, Zhao Y, Woodfield SE, Zhang H, Xu X, Yu Y, Zhao J, Bieerkehazhi S, Liang H, Yang J, Zhang F, Sun S. TAK1 inhibitor 5Z-7-oxozeaenol sensitizes cervical cancer to doxorubicin-induced apoptosis. Oncotarget. 2017; 8:33666-75. https://doi.org/10.18632/oncotarget.16895. [PubMed]

41. Li J, Liang C, Zhang ZK, Pan X, Peng S, Lee WS, Lu A, Lin Z, Zhang G, Leung WN, Zhang BT. TAK1 inhibition attenuates both inflammation and fibrosis in experimental pneumoconiosis. Cell Discov. 2017; 3:17023. https://doi. org/10.1038/celldisc.2017.23. [PubMed]

42. Ghandi M, Huang FW, Jané-Valbuena J, Kryukov GV, Lo CC, McDonald ER 3rd, Barretina J, Gelfand ET, Bielski CM, Li H, Hu K, Andreev-Drakhlin AY, Kim J, et al. Next-generation characterization of the Cancer Cell Line Encyclopedia. Nature. 2019; 569:503-08. https://doi. org/10.1038/s41586-019-1186-3. [PubMed]

43. Sakai H, Sato A, Aihara Y, Ikarashi Y, Midorikawa Y, Kracht M, Nakagama H, Okamoto K. MKK7 mediates miR-493-dependent suppression of liver metastasis of colon cancer cells. Cancer Sci. 2014; 105:425-30. https:// doi.org/10.1111/cas.12380. [PubMed]

44. Qiu F, Yang L, Lu X, Chen J, Wu D, Wei Y, Nong Q, Zhang L, Fang W, Chen X, Ling X, Yang B, Zhang X, et al. The MKK7 p.Glu116Lys Rare Variant Serves as a Predictor for Lung Cancer Risk and Prognosis in Chinese. PLoS Genet. 2016; 12:e1005955. https://doi.org/10.1371/journal. pgen.1005955. [ [ $\underline{\text { PubMed] }}$
45. Uhlén M, Fagerberg L, Hallström BM, Lindskog C, Oksvold P, Mardinoglu A, Sivertsson Å, Kampf C, Sjöstedt E, Asplund A, Olsson I, Edlund K, Lundberg E, et al. Proteomics. Tissue-based map of the human proteome. Science. 2015; 347:1260419. https://doi.org/10.1126/ science.1260419. [PubMed]

46. Nishina H, Vaz C, Billia P, Nghiem M, Sasaki T, De la Pompa JL, Furlonger K, Paige C, Hui C, Fischer KD, Kishimoto H, Iwatsubo T, Katada T, et al. Defective liver formation and liver cell apoptosis in mice lacking the stress signaling kinase SEK1/MKK4. Development. 1999; 126:505-16. [PubMed]

47. Rincón M, Whitmarsh A, Yang DD, Weiss L, Dérijard B, Jayaraj P, Davis RJ, Flavell RA. The JNK pathway regulates the In vivo deletion of immature CD4(+)CD8(+) thymocytes. J Exp Med. 1998; 188:1817-30. https://doi. org/10.1084/jem.188.10.1817. [PubMed]

48. Sakurai H, Nishi A, Sato N, Mizukami J, Miyoshi H, Sugita T. TAK1-TAB1 fusion protein: a novel constitutively active mitogen-activated protein kinase kinase kinase that stimulates AP-1 and NF-kappaB signaling pathways. Biochem Biophys Res Commun. 2002; 297:1277-81. https://doi.org/10.1016/s0006-291x(02)02379-3. [PubMed]

49. Gu Z, Eils R, Schlesner M. Complex heatmaps reveal patterns and correlations in multidimensional genomic data. Bioinformatics. 2016; 32:2847-49. https://doi.org/10.1093/ bioinformatics/btw313. [PubMed]

50. Ritchie ME, Phipson B, Wu D, Hu Y, Law CW, Shi W, Smyth GK. limma powers differential expression analyses for RNAsequencing and microarray studies. Nucleic Acids Res. 2015; 43:e47. https://doi.org/10.1093/nar/gkv007. [PubMed] 